\title{
The Relationship between Forest and Land Rehabilitation with the Quality and Health of Watershed in Indonesia
}

\author{
Wahyudi Susanto ${ }^{1}$ \\ Ministry of National Development Planning Agency/Bappenas - Indonesia
}

\begin{abstract}
This study estimates the relationship between Forest and Land Rehabilitation policies and the quality and health of watersheds measured by the Coefficient of Flow Regime. The method used is the estimation of the Granger causality relationship. The results of this study indicate that in the short term or less than three years of forest and land rehabilitation does not have a significant relationship with the good value of the coefficient of flow regime. It is hoped that with these findings, the government can review the methodology, institutional system, location, quality of materials and tools for forest and land rehabilitation by taking into account the natural and geographical conditions around the watershed. furthermore, the government can implement other measures to support forest and land rehabilitation in accordance with existing regulations.
\end{abstract}

Keywords: Granger Causality, Forest and Land Rehabilitation, Watershed.

\footnotetext{
${ }^{1}$ Wahyudi Susanto is a Junior Planner Directorate of Forestry and Conservation of Water Resources, Ministry of National Development Planning/BAPPENAS RI. Email: wahyudi.susanto@bappenas.go.id
} 


\section{The Relationship Between Forest and Land Rehabilitation with The Quality and Health of Watershed in Indonesia}

Wahyudi Susanto

\section{Introduction}

According to Dye (1981), public policy is whatever the government chooses to do whatever does not do something. Anderson in Subarsono (2008, 44) define public policy is determined by government bodies and authorities. But on the other hand, it is important to realize that public policies can also be carried out by actors outside the government. The participating stakeholders must participate in the discussion. Policymakers must continue to engage in dialogue with all stakeholders to analyze all implementation policies. Thus, the evaluation of policy implementation needs to be done to see accountability and its impact on the public.

One interesting public policy to be examined is the policy of forest and land rehabilitation (FLR) in the Watershed. Law Number 31 of 1999 concerning Forestry discusses what is related to governance to improve the prosperity of the people that is just and sustainable, the community can provide advice, information and conduct oversight in forestry development. Forests that become the foundation for the effort of the protection of environment with the land conservation and water resources are increasingly moving away from the community's right to get good environmental quality, as an impact of the poor forestry management by the government.

The adequacy of forest cover and the size of the forest area is guaranteed by the government. Since the enactment of the Forestry Law, efforts to implement forest management have not been good in responding to the adequacy of forest cover in watersheds. The general explanation of the Forestry Law states that to fulfill the balance of environmental benefits, socio-cultural benefits, and economic benefits, the government determines and maintains the adequacy of the area of the forest within the watershed and / or island with a proportional distribution. The minimum area of forest area that must be protected is at least 30 percent (thirty percent) of the total watershed and/or island area of the land area. In accordance with Minister of Forestry Regulation Number P.61/Menhut-II/2014 concerning Monitoring and Evaluation of Watershed Management, monitoring various watershed performance indicators including biophysical, hydrological, socio-economic components, building investment and spatial use of watershed areas is an effort to collect and collect data and information needed for the purpose of evaluating watershed management performance.

According to the Decree of the Minister of Forestry Number 328 of 2009 concerning the Establishment of Priority Watersheds in the framework of the 20102014 Medium-Term Development Plan, 108 priority watersheds have been established as guidelines/references for relevant agencies/offices in setting priority priorities for forest and land rehabilitation activities. Subsequently, the Ministry of the Environment determined the priority scale of 15 watersheds, namely Asahan Toba, Ciliwung, Citarum, Bengawan Solo, Brantas, Moyo, Kapuas, Jeneberang, Siak, Musi, Village, Cisadane, Serayu, Limboto, and Saddang. However, forest and land rehabilitation activities during 2014-2019 focused on 10 priority watersheds, Asahan Toba, Musi, Sekampung, Citarum, Solo, Serayu, Brantas, Jeneberang, Limboto, and Moyo. The indicator is used in assessing the quality, continuity, and 
quantity of water is the Coefficient of Flow Regime (CFR), which is to determine between the maximum discharge and minimum discharge.

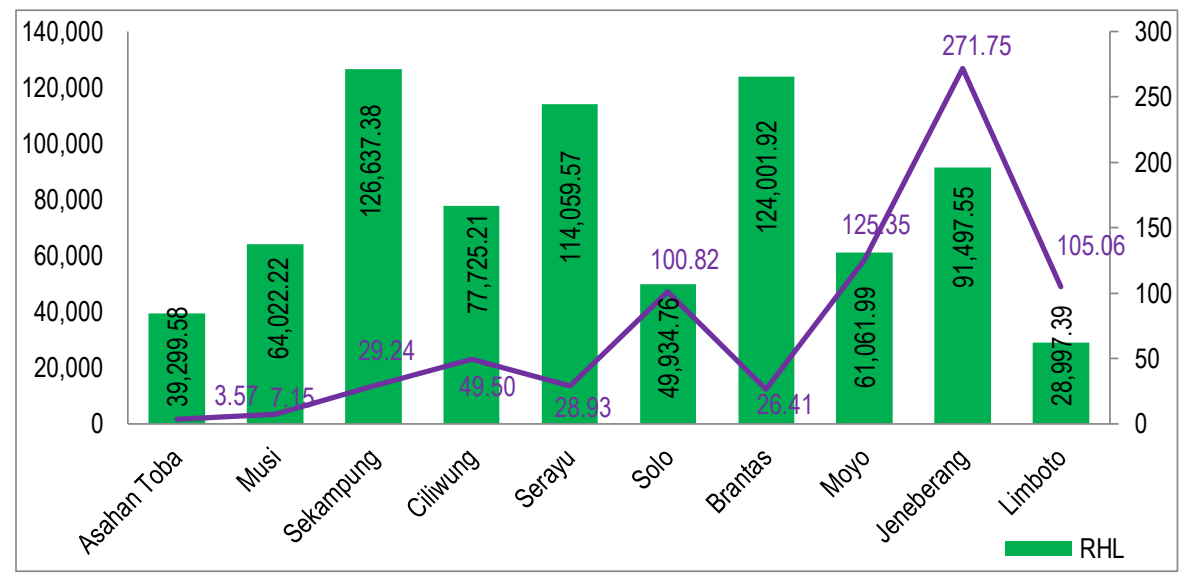

Figure 1. Comparison of RHL with KRA in 10 priority watersheds for the 20132018 period

Sources: Forestry Statistics, KLHK 2018

Based on Figure 1.1, it can be seen that there are three watersheds with the highest area of FLR from 2013 to 2018, namely, Serayu and Brantas. Meanwhile, there are three watersheds that received FLR with a relatively small area, namely, Asahan Toba, Solo, and Limboto Watersheds. On the other hand, CFR values in Jeneberang were the highest with 271.75 and the Moyo is 125.35, when compared with the CFR classification it was very high $(>120)$. Watersheds that have high CFR values (100-120) are Solo and Limboto. The watersheds that have low CFR values $(<50)$ consist of Asahan Toba, Musi, Sekampung, Ciliwung, Serayu and Brantas. If you look at the data, it can be assumed that FLR activities in watershed with an area larger than the area in other watersheds will not necessarily result in lower CFR values. It's very interesting to find out more whether the FLR that has been carried out has a positive impact or are there other factors that affect the CFR value in the watershed.

Based on the data in Figure 1.1, it can be seen the fluctuating relationship between FLR and CFR. Therefore, this research needs to be done to study the relationship between FLR and CFR in the ten priority watersheds. It's expected that the results of this study can help the government to improve FLR policies, methodologies, and implementation of policy systems.

\section{Literature Review}

\subsection{Public Policy in the Forestry Sector}

The state gives authority in the control of forests to the government. Therefore, the government must be present in forest management not only in terms of forest utilization. In accordance with the mandate of the Forestry Law, the government is responsible for restoring natural forest cover and preventing forest destruction. Then, the Forestry Law also mandates the government to be present at the site level in forest management by realizing the Forest Management Unit (FMU). FMU is a node that connects the interests of the center with the region, including resolving various conflicts and problems that have not ended. Natural forest cover that 
continues to shrink has great potential to cause poor performance of a watershed resulting in erosion, flooding, and drought.

In connection with watershed management, forestry operations must guarantee the existence of forests with sufficient size and proportional distribution and increase the carrying capacity of watersheds. Government Regulation Number 37 of 2012 Concerning Watershed Management Article 14 mentions the criteria for water quality, quantity and continuity, as referred to in article 12 paragraph 3 letter b, at least contains sub-criteria: a. coefficient of flow regime; b. coefficient of the annual flow; c. sediment load; d. flood; e. index of water use. The inadequacy of the extent of forest cover and forest area in efforts to protect forests and nature conservation in the watershed area causes a decline in the basic functions of the forest ecosystem itself.

The indicator used in assessing the quality, continuity, and quantity of water is the Flow Regime Coefficient (KRA), which is to determine between the maximum discharge and minimum discharge with the following classification.

Table 1. Coefficient of Flow Regime

\begin{tabular}{ccc}
\hline No. & Value & Classification \\
\hline 1 & CFR $\leq 20$ & Very Low \\
2 & $20<\mathrm{CFR} \leq 50$ & Low \\
3 & $50<\mathrm{CFR} \leq 80$ & Moderate \\
4 & $80<\mathrm{CFR} \leq 110$ & High \\
5 & $\mathrm{CFR}>110$ & Very High \\
\hline
\end{tabular}

\subsection{Review of Study of Watershed}

Toban, et. al (2016) examine watershed performance based on land use and water discharge indicators in the Unda watershed. Results, percentage value assessment, vegetation cover in Unda watershed during the period 2006-2013 included in the medium class with a value of $53-55 \%$. Furthermore, the value of the coefficient of flow regime before the issuance of the draft of Integrated Watershed Management Plan (IWMP) in 2006-2009 was in the range 67.66 which included the medium class and after the issuance of the IWMP in the 2010-2013 period was moved according to 18.8 which included very low classes. Based on observations and sought criteria, Unda watershed performance after the issue of the IWMP can be said to be getting better. Yohan Surtiani and Lilin Budiati (2015) evaluated FLR in the Juwana watershed in the Mount Muria of Pati Regency. The method used is a mixture of quantitative methods through priority ranking scale determined from the questionnaire and qualitative methods through interviewees or direct observation in the field. The result is the success of RHL in the Juwana watershed reached $65.8 \%$. Didid Sulastyo, Hariadi Kartodihardjo dan Sudarsono Soedomo (2016) discuss the effectiveness of implementing forest rehabilitation and reclamation policies. The method used is the analysis of regulatory texts to see what extent the regulatory texts address various problems in the field. The result is in implementing RHL policies there are irregularities, high transaction costs, low participation and low legitimacy caused by ineffective communication, bureaucratic structure, disposition/character and resources. Aris Jatmiko, Ronggo Sadono dan Lies Rahayu W.F. (2012) evaluate FLR activities using multi-criteria analysis. The method used is a hierarchical analysis process. The result, the percentage of the 
success rate of RHL activities was $70,55 \%$. These results are included in the moderate criteria and need to be improved in the future

\subsection{Watershed Management}

Government Regulation Number 37 of 2012 concerning Management of Watersheds in Article 1 Paragraph 1 states that watersheds are land areas which are an integral part of rivers and their tributaries, which function to store, saving, and draining the water from rainfall to the lake or to the sea naturally, the boundary on land is the topographic separator and the boundary in the sea to waters that are still affected by land activities. Then, Article one Paragraph two states that watershed management is a human effort in regulating the reciprocal relationship between natural resources and humans in the watershed and all its activities so that the sustainability and harmony of the ecosystem can be realized as well as the increased use of natural resources for humans in a sustainable manner. Pursuant to Article one Paragraph three, watershed classification is a categorization of watershed-based on land conditions and the quality, quantity and continuity of water, socioeconomic, investment in water construction and spatial use.

Article 36, Government Regulation Number 37 of 2012 concerning Watershed Management in Paragraph one states that the watershed management plan as referred to in Article 35 is stipulated for a period of 15 (fifteen) years. Furthermore, Paragraph two states that the watershed management plan referred to in paragraph one is evaluated and reviewed every five years. Judging from the above government regulations, it is necessary to evaluate the impact of the watershed management plan on the health and watershed quality indicators every five years to see whether the plans issued are in accordance with the implementation and expected results.

One issue of complexity is the issue of watershed management. Pambudi (2019) examined the effectiveness of watershed management policies in Indonesia in terms of history, regulation, institutions and policy implementation. The method used is reviewing the Integrated Watershed Management Plan (RPDAST), River Area Territory Plan, Spatial and Regional Plan (RTRW), National Medium-Term Development Plan (RPJMN), and Ministry / Institution / Regional Regulation related to the watershed. The review used is translated into a SWOT analysis, then enriched with data generated by interviews, discussions and secondary data searches. The result is a watershed management plan and existing regulations must be integrated with community institutions to maintain the ecology and interdependent relationship between nature and people.

\subsection{Granger Causality Test}

The Granger Causality Test method is used to determine the cause and effect of two groups of data which in theory have not been tested in the direction of the relationship so it is assumed that the two variables to be tested can be endogenous or exogenous variables. The concept of causality testing was proposed by Clive William John Granger in 1969 by investigating the relationship between variables in econometric modeling. Granger test results are predictions of cause and effect relationships that can be supported by testing Vector Auto Regression (VAR) and Vector Error Correction Model (VECM). Granger Causality Test is usually used in statistical data estimation and causal theory. Because it may be that the impact of certain variables is caused more by itself or other variables.

The Granger modeling method can be written in the following equation formulation. 


$$
X(t)=\sum_{\tau=1}^{L} A_{\tau} X(t-\tau)+\varepsilon(t)
$$

annotation:

$$
\begin{array}{ll}
\varepsilon(t) & =\text { Gaussian random vector } \\
A_{\tau} & =\text { matrix from } \tau \\
X(t) & =\text { individual variable data }
\end{array}
$$

\section{Methodology}

\subsection{Research Design}

The limitation of this research discussion is about the relationship between Forest and Land Rehabilitation (RHL) and Watershed Performance (DAS) measured based on the Flow Regulatory Coefficient (KRA) indicator. The proposed econometric model is the Granger Causality Test. Granger analysis is intended to see the direction of the relationship between variables. The design of this study uses a descriptive quantitative research design that is the preparation of tables to explain the direction of the relationship between FLR variables and FCR variables in the ten priority watersheds namely, Toba Asahan, Musi, Village, Ciliwung, Serayu, Solo, Brantas, Moyo, Jeneberang, and Limboto. To make it easier to understand the flow of this action plan report, it will be illustrated in the following flowchart.

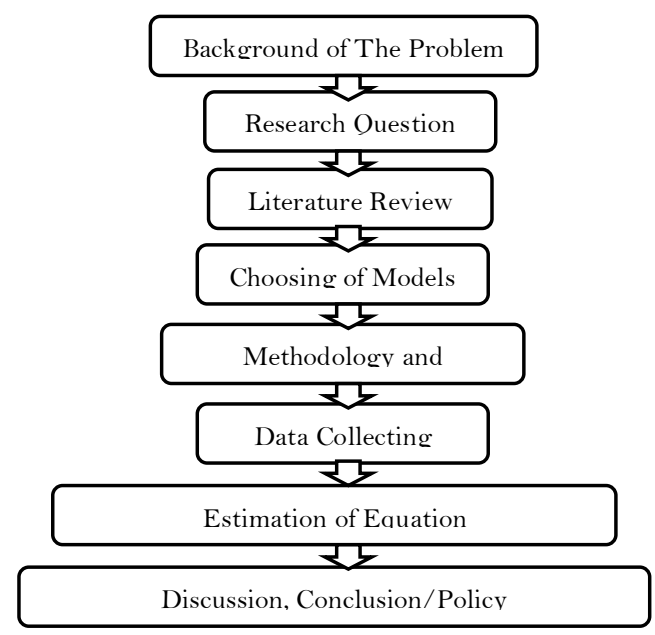

Figure 1. Research Flow Chart

\subsection{Definition of Operational Variables}

To equate perceptions about the variables used in the concept of modeling this study, the operational definition is described as follows.

1. The watershed interpreted as an area around a river which in this study is a watershed that is a priority of the Ministry of Environment and Forestry (KLHK) to be improved and maintained by the spring.

2. Forest and Land Rehabilitation (FLR), KLHK defines forest and land rehabilitation in the upstream part of the watershed which is prone to floods, droughts and landslides, catchment areas from reservoirs, dams and lakes, watersheds in upstream watersheds, river border areas, springs, lakes and reservoirs as well as downstream parts of the watershed which are prone to tsunami disasters, sea water intrusion and coastal abrasion. 
3. The coefficient of Flow Regime is a unit/index that is used to define the ratio between maximum discharge and minimum river discharge. The smaller the FCR value is an indicator the better the watershed's ability to hold river water runoff.

\subsection{The Data Used}

The data to be used in this study is sourced from the Ministry of Environment and Forestry's Forestry Statistics. The data consists of FCR data which are indicators of the quality and health of watersheds and FLR data around priority watersheds for the period of 2013 to 2018.

\subsection{Analysis Tools and Techniques}

This study uses the Granger Causality Test to see the direction of the relationship between two interest variables. The use of the Granger Causality Test is expected to help the analysis of the direction between variables and policy interventions that will be applied whether sequence or parallel type.

Before estimating, the data is done by unit root test with Augmented DickyFuller (ADF) on each variable. Optimum lag testing and cointegration procedures will be used to find better structure equation models whether using the Vector Auto Regression (PVAR) Panel or the Vector Error Correction Model (PVECM). If cointegration testing is found in the variables, the estimation that will be used is PVECM to see the short-term and long-term relationships between variables.

The initial equation of the model is assumed to be the PVAR model used to describe the causality relationship:

$Y_{i t}=\alpha_{0}+\alpha_{1} Y_{i t-1}+\alpha_{2} Y_{i t-n}+\beta_{1} X_{i t-1}+\beta_{2} X_{i t-n}+\mu_{i t}$

$X_{i t}=\gamma_{0}+\gamma_{1} X_{i t-1}+\gamma_{2} X_{i t-n}+\delta_{1} Y_{i t-1}+\delta_{2} Y_{i t-n}+v_{i t}$

annotation:

$\Upsilon=$ endogenous variable 1

$X=$ endogenous variable 2

Before the causality test is carried out, a test is carried out on the model that has been prepared with stationary testing, cointegration testing, optimal lag selection and then a Granger test is performed. Causality testing aims to ensure the direction of the relationship between the variables to be tested. In this study, the direction of the relationship between FLR and interest variables will be tested, namely the FCR variable.

\section{Discussion}

The data analyzed were taken as many as 60 observations from 10 priority watersheds during the period of 2013 to 2018 consisting of the Toba Asahan, Musi, Sekampung, Ciliwung, Serayu, Solo, Brantas, Moyo, Jeneberang, and Limboto Watersheds. All data is taken from forestry statistics released by the Ministry of Environment and Forestry. The following is a summary table of data that will be used in the analysis. 
Table 1. Summary of Research Data

\begin{tabular}{cccccc}
\hline Variable & Obs. & Mean & Std. Dev. & Min. & Max. \\
\hline FCR & 60 & 62,31 & 96,52 & 0,00 & 481,27 \\
FLR & 60 & $12.953,96$ & $12.998,40$ & 35,72 & $60.185,71$
\end{tabular}

\subsection{Stationerity test}

Source: forestry statistics, processed (KLHK 2013-2018)

As the first step in data analysis, it is necessary to do a unit root test of the variables in the discussion of causality in this study, namely the FCR variable and the FLR variable. Unit root testing uses the method of the Augmented DickeyFuller Test (ADF) and Levine-Liu-Chu Test. The data is said to be stationary if the statistical test value is smaller than the critical value of at least $5 \%$ which is -2.8671 and the probability value is smaller than 0.05 . From the test results in Table 4.2 it can be seen that the FCR data in I (0) or data at the level shows that there is no unit root because the statistical test value is -3.4080 and it is smaller than the critical level of $5 \%(-2.8671)$, so the data said to be stationary. Next, the FLR data test results show a value of -6.4586 and smaller than the critical level of $1 \%(-3.5460)$ so the data is said to be stationary. With these results, there is no need to do a different first on the data.

Table 2. Unit root test for FLR and FCR variables with the Augmented DickeyFuller method on data $\mathrm{I}(0)$

\begin{tabular}{cccc}
\hline & $\begin{array}{c}\text { t- } \\
\text { Statistic }\end{array}$ & Prob. $^{*}$ & Status \\
\hline Augmented Dickey-Fuller test statistic & & \\
FCR & - & 0,0165 & stasionary \\
FLR & $3,4080^{* * * *}$ & & \\
& - & 0,0000 & stasionary \\
& $6,4586^{* * * *}$ & & \\
\hline
\end{tabular}

MacKinnon (1996) one-sided p-values.

Annotation: **** significant at level $1 \%$.

Source: forestry statistics, processed (KLHK 2013-2018)

\subsection{Cointegration test}

Cointegration testing is used to determine the relationship between the variables in the long run, in this case, the FLR and FCR variables. Cointegration testing uses the Pedroni Residual Cointegration Test method by comparing the probability values of seven-panel categories. The seven-panel categories are the vstatistics panel, the rho-statistics panel, the PP-statistics panel, the ADF-statistics panel, the rho-statistics group, the PP-statistics group and the ADF-statistics group. If the probability value of the seven criteria is less than 0.05 , the null hypothesis that FLR and FCR do not have cointegration cannot be rejected. Conversely, if the probability value is greater than 0,05 , the null hypothesis can be rejected. In cointegration testing, the FLR $\left(\mathrm{y}_{1}\right)$ and $\mathrm{FCR}\left(\mathrm{y}_{2}\right)$ variables will be tested.

Following is the equation model that will be performed cointegration test.

$$
\begin{aligned}
& F L R=\alpha_{o}+\alpha_{t} F C R+e_{t} \\
& \Delta F L R=\alpha_{o}+\alpha_{t} \Delta F C R+e_{t}
\end{aligned}
$$


Table 3. Result of Cointegration test by Pedroni Residual Cointegration Test at the data level

\begin{tabular}{lcc}
\hline RHL and KRA Variable & Statistic & Prob. \\
\hline Panel v-Statistic & -0.754193 & 0.7746 \\
Panel rho-Statistic & 0.730891 & 0.7676 \\
Panel PP-Statistic & -2.639 .709 & 0.0041 \\
Panel ADF-Statistic & $\mathrm{NA}$ & $\mathrm{NA}$ \\
Group rho-Statistic & 1.869 .344 & 0.9692 \\
Group PP-Statistic & -4.236 .875 & 0.0000 \\
Group ADF-Statistic & $\mathrm{NA}$ & $\mathrm{NA}$ \\
\hline
\end{tabular}

Source: forestry statistics, processed (KLHK 2013-2018)

The test results in Table 4.3 can be seen that there has been a cointegration in the data level of the testing model $\mathrm{I}(0)$. Therefore, the analysis continued with the Panel Vector Error Correction Model (PVECM). That is because the two variables occur long-run relationship, while the Panel Vector Autor Regression (PVAR) requires that no cointegration between variables to be estimated.

\subsection{Lag Optimal Selection}

Before testing the Panel Vector Error Correction Model (PVECM) model, it is necessary to choose the optimum lag selection. According to Amri (2017), Optimal lag selection is used to determine the time period of the influence of a variable on other variables optimally. Knowledge of optimal lag due to the impact of changing a variable on other variables does not always occur in the same time period. The impact of changing these variables can occur at different time periods. Widarjono (2009, 243) says that the important thing to do in analyzing the PVAR / PVECM model is to determine the length of the lag. Therefore, before entering into the PVECM model it is necessary to know the optimal lag estimation that gives a significant effect or response.

If you look at Table 4.4, it can be seen that the optimal lag choice is the 3year time horizon generated by LR statistical tests, Final Predictor Error (FPE), Akaike Information Criterian (AIC), Schwarz Information Criteria (SIC) and Hannan-Quinn Information Criterian (HQ). The optimal lag option will be used for an optimal lag in a 3-year time horizon because with consideration of the longer time period so that it is possible to provide a more optimal inter-variable influence.

Table 4. Result of Lag Optimal Selection

\begin{tabular}{ccccccc}
\hline Lag & LogL & LR & FPE & AIC & SC & HQ \\
\hline $\mathbf{0}$ & -3.242 .414 & NA & $5.05 \mathrm{e}+11$ & 3.262 .414 & 3.272 .372 & 3.264 .358 \\
$\mathbf{1}$ & -3.195 .653 & 7.949 .462 & $4.74 \mathrm{e}+11$ & 3.255 .653 & 3.285 .525 & 3.261 .484 \\
$\mathbf{2}$ & -3.022 .936 & $25.90756^{*}$ & $1.28 \mathrm{e}+11$ & 3.122 .936 & 3.172 .722 & 3.132 .655 \\
$\mathbf{3}$ & -2.952 .197 & 9.196 .016 & $9.80 \mathrm{e}+10^{*}$ & $30.92197^{*}$ & $31.61898^{*}$ & $31.05804^{*}$ \\
\hline
\end{tabular}

Source: forestry statistics, processed (KLHK 2013-2018)

\subsection{Granger Causality Test}

The Indonesian Journal of Development Planning

Volume III No. 3 - December 2019 
Granger Causality Test is conducted to determine the direction of causality between FLR and FCR. Based on the test results in Table 4.5, it is known that there is a significant one-way relationship in the fourth lag, FLR to FCR. Meanwhile, FCR has no significant effect on FLR in the short run and long run. Meanwhile, in the short-run (less than 3 years) there was no significant relationship between both FLR to FCR and FCR to FLR.

Table 5. Results of Granger Causality Test

\begin{tabular}{c|ccccc}
\hline Endogenous Variable & \multicolumn{5}{|c}{ Exogenous Variable } \\
\hline \multirow{3}{*}{ FCR } & $\operatorname{Lag} 1$ & $\operatorname{Lag} 2$ & $\operatorname{Lag} 3$ & $\operatorname{Lag} 4$ \\
\hline & 0,0858 & 0,6608 & 0,4010 & $3.926,94$ \\
& {$[0,7712]$} & {$[0,5252]$} & {$[0,7546]$} & {$[0,0120]$} \\
& \multicolumn{5}{c}{ FLR } \\
\hline \multirow{2}{*}{ FLR } & 0,1175 & 1,0786 & 0,5277 & 1,5539 \\
& {$[0,7337]$} & {$[0,3554]$} & {$[0,6710]$} & {$[0,5326]$} \\
\hline
\end{tabular}

\section{Closing}

\subsection{Conclusion}

Since the era of decentralization, the central government and regional governments must work together in facing challenges to overcome watershed problems in accordance with fiscal characteristics and capabilities. In this case, the Ministry of Environment and Forestry has a Watershed and Protection Forest Management Agency (BPDASHL) that handles regional watersheds. In the framework of the recovery and maintenance of watershed sustainability, it is necessary to involve inter-sectors including APBN planning, sector/program/project planning to the level of coordination of all relevant agencies or institutions in watershed management. From this research, it can be seen that watershed management and efforts to rehabilitate forests and land in watersheds are not running optimally using the following.

1. The causality between FLR and FCR occurs in one direction in the long term ( $>4$ years), that is, RHL Affects KRA while KRA does not affect RHL. However, RHL has an effect on KRA with a positive value of 0,0072.

2. Short-run causality of fewer than 3 years shows that RHL and KRA are not interconnected.

From the conclusions above, the government needs to evaluate FLR policies and optimize institutional integration and partnerships with the community in accordance with PP 37 of 2012 Article 40 which states that watershed management includes:

1. optimizing land use according to the function and carrying capacity of the region;

2. the application of soil and water conservation techniques is carried out in the context of maintaining the sustainability of water catchments, maintaining the quality, quantity, continuity, and distribution of water; 
3. Vegetation management is carried out in order to preserve biodiversity, increase land productivity, ecosystem restoration, rehabilitation, and land reclamation;

4. Increased awareness and participation of related agencies in watershed management; and/or

5. Institutional development of watershed management to improve coordination, integration, synchronization, and synergy across sectors and administrative regions.

In addition, the government needs to inventory the watershed and classify it so that watershed erosion prevention can be done early both vegetatively and civically (retaining dams, controlling dams, infiltration wells and gully plugs.

\subsection{Limitations}

1. The data used is limited to 10 priority watersheds out of around 108 priority watersheds determined by the Ministry of Environment and Forestry (KLHK).

2. The research method is limited to the data owned by the method of Granger causality test so that the estimation has not been carried out with the variant decomposition analysis and impulse response function to determine the turmoil due to intervention on one of the variables in the long run.

3. The author assumes that the data obtained has a broad range of views from the year, thus such recording is assumed to be FLR benefits not acceptable in the short run.

\section{References}

Bernard J.C. and Willet 1.S. 1996. "Asymmetric Price Relations in the U.S. Boiler Industry.” Journal of Agricultural and Applied Economics, Vol. 28 (2). 279-289.

Diansari, R. E. (2016). Analisis Kesiapan Desa dalam Implementasi Penerapan Undangundang Nomor 6 Tahun 2014 tentang Desa: Studi pada Desa Pateken Kecamatan Wonoboyo Kabupaten Temanggung Jawa Tengah. Jogyakarta: Universitas PGRI Yogyakarta. Retrieved from http://repository.upy.ac.id/878/

Dye, Thomas R.. 1981. Understanding Public Policy (4th Edition). Englewood Cliff, NJ: Prentice-Hall Inc, Ltd.

Enders, Walter. 1995. “Applied Econometric Time Series.” New York: John Willey and Sons.

Forest Watch Indonesia, 2016.

Gaspersz, Vincent. 1991. "Uji Heteroskedasitas". Binus University, 20 November 2015. Diakses pada 28 September 2018. http://sbm.binus.ac.id/2015/11/20/uji-asumsi-klasik-uji-heteoskedasitas/

Gertler, P.J., Martinez, S., Premand, P., Rawlings, L.B., and Vermeersch, C.M.J. 2011. Impact Evaluation in Practice. World Bank. Washington D.C.

Government of Indonesia (2009); Minister of Forestry Decree (Keputusan Menteri Kehutanan) SK.328/Menhut-II/2009 about Priority Watershed on Mid-Term Development Plan (RPJMN) $2010-2014$.

Government of Indonesia (2012); Government Regulation (Peraturan Pemerintah) Number 37 Year 2012 about Watershed Management.

Government of Indonesia (2014); Law (Undang-undang) Number 37 Year 2014 about Soil and Water Conservation.

Granger, C. 1969. "Investigating Causal Relations by Econometric Models and Cross-spectral Methods.” Econometrica, 37 (3): 424-438.

Granger, C. and P. Newbold. 1974. "Spourious Regressions in Econometrics." Journal of Econometrics, Vol. 2, 111-120. 
Jatmiko, Aris, Ronggo Sadono dan Lies R.W.F. 2012. "Evaluasi Kegiatan Rehabilitasi Hutan dan Lahan Menggunakan Analisis Multikriteria (Studi Kasus di Desa Butuh Kidul Kecamatan Kalikajar Kabupaten Wonosobo Jawa Tengah”. Jurnal Ilmu Kehutanan, Vol. VI, No. 1. 2012.

Khandker, S.R., Koolwal, G.B., dan Samad, H.A. 2010. "Handbook on Impact Evaluation: Quantitative Methods and Practices". World Bank. Washington D.C.

Koutsoyiannis, A. (1977). Theory of Econometrics: An Introductory Exposition of Econometric Methods, $2^{\text {nd }}$ Edition, MacMillan Publishers,Ltd.

Pambudi, Andi Setyo. 2019. "Watershed Management in Indonesia: A Regulation, Institution, and Policy Review". The Indonesian Journal of Development Planning, Vol. III, No. 2. 2019.

Paul A. Samuelson. 1954. "The Review of Economics and Statistics", Vol. 36, No. 4. (Nov., 1954), pp. 387-389.

Sims, C.A. 1972. "The Role of Approximate Prior Restriction in Distributed Lag Estimation." Journal of American Statistical Association, Vol. 67, 169-175.

Soehartono, Irawan, 2007. Kebijakan Sosial Sebagai Kebijakan Publik, Alfabeta, Bandung.

Subarsono, Ag. Analisi Kebijakan Publik, 2008. Pustaka Pelajar. Yogyakarta.

Sulastyo, Didid, Hariyadi Kartodihardjo dan Sudarsono Soedomo. 2016. "Efektivitas Implementasi Kebijakan Rehabilitasi dan Reklamasi Hutan”. Jurnal Silvikultur Tropika, Vol. 7, No. 3. 2016.

Surtiani, Yohan dan Lilin Budiati. 2015. "Evaluasi Rehabilitasi Hutan dan Lahan di Daerah Aliran Sungai Juwana pada Kawasan Gunung Muria Kabupaten Pati”. Jurnal Pembangunan Wilayah dan Kota, Vol. 11, No.1. 2015.

Susamto, Akhmad Akbar. 2014. Pelatihan Impact Evaluation: Menggunakan Model Mikroekonometris Berbasis Stata. Modul tidak diterbitkan, Fakultas Ekonomika dan Bisnis. UGM, Yogyakarta.

Toban, Edoardo Wahyudi, I Nyoman Sunarta dan Ni Made Trigunasih. 2016. "Analisis Kinerja Daerah Aliran Sungai Berdasarkan Indikator Penggunaan Lahan dan Debit Air Pada DAS Unda”. E-Jurnal Agrokoteknologi Tropika, Vol. 5, No.4. 2017.

Undang-Undang Nomor 41 Tahun 1999 Tentang Kehutanan.

Wahab, Solihin Abdul Wahab, 2008. Pengantar Analisis kebijakan public. UMM Press. Malang.

Widarjono, Agus. 2009. Ekonometrika Pengantar dan Aplikasinya. Edisi Ketiga. Yogyakarta: Ekonisia.

Wooldridge, J.M. 2015. Introductory Econometrics: A Modern Approach. Cengange Laarning, Michigan State University. 